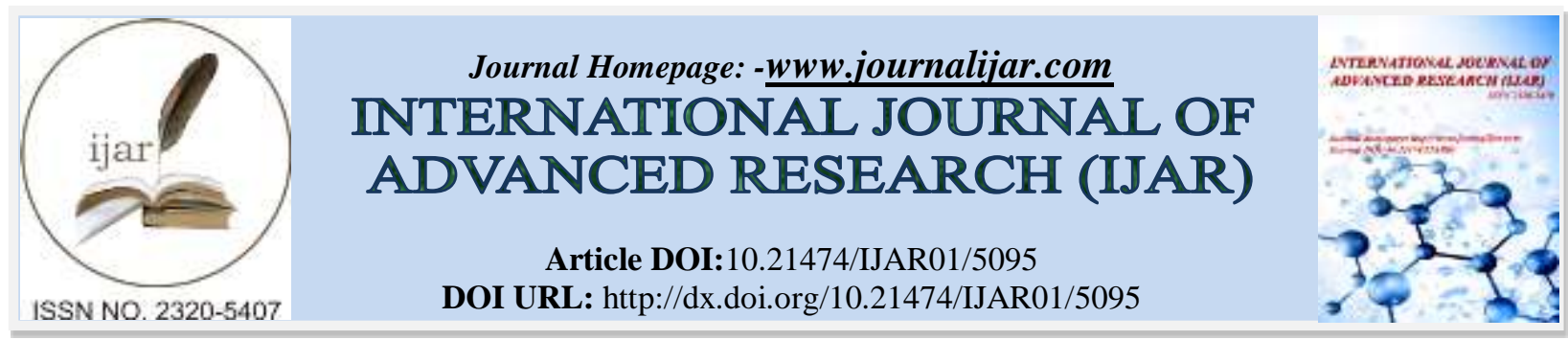

RESEARCH ARTICLE

\title{
PROGNOSTICATION OF NF-KB AND P53 EXPRESSION IN DIFFERENT STAGE AND GRADE OF OVARIAN CANCER.
}

\section{Dr. Debarshi Jana ${ }^{1}$, Dr. Sambhunath Bandyopadhyay ${ }^{1}$, Priyanka Upadhyay ${ }^{2}$, Dr. Arghya Adhikary ${ }^{2}$ and Dr. Asim Kumar Manna ${ }^{1}$.}

1. Department of Gynecology \& Obstetrics, Institute of Post-Graduate Medical Education and Research, A.J.C. Bose Road, Kolkata-700020, West Bengal, India

2. Centre for research in nanoscience \& nanotechnology, acharya prafulla chandra roy sikhsha prangan, university of Calcutta, jd-2, sector 3, salt lake city, kolkata-700108, West Bengal, India.

\section{Manuscript Info}

Manuscript History

Received: 07 June 2017

Final Accepted: 09 July 2017

Published: August 2017

Key words:-

Ridge splitting, Expansion, Guided bone regeneration.

\begin{abstract}
Introduction: Incidence of ovarian cancer is increasing in female population in urban India. Till now most of the treatments are guided by the tumor parameters and many occasions the results of treatment have been unpredictable. This study aims to various molecular factors and will try to link then with the tumor factors. This study was evaluated prognostic significance of like NF- $\mathrm{KB}$ and p53 expression in ovarian cancer patients.

Material and Methods: In this hospital based study 106 ovarian cancer patients attend at OPD in our institute of Eastern India. NF- $\kappa B$ and p53 protein expression was measured from cancer tissue sample by both Western Blot and RT-PCR Technique. For statistical analysis data were entered into a Microsoft excel spreadsheet and then analyzed by SPSS 20.0.1 and Graph Pad Prism version 5 .

Results: NF- $\mathrm{kB}$ was overexpressed with $66(66.2 \%)$ patients and p53 was activated with $69(65.21 \%)$ patients in ovarian carcinoma in Indian population. Statistically significant associations of NF-KB and p53 positive tumors were found in advance stage, grade, histopathology type and lymph node metastasis. It was showed that poor prognostic outcome was observed in NF- $\mathrm{KB}$ and p53 activated ovarian cancer patients.

Conclusions: It was concluded NF- $\kappa \mathrm{B}$ and $\mathrm{p} 53$ is an independent prognostic and predictive marker of Indian ovarian cancer. Thus the study can in a pioneering work in establishing new risk stratification system which will be an importance selecting appropriate adjuvant therapy following surgery. No such host-tumor integrating study has come out from this subcontinent and therefore is be of importance in establishing ovarian cancer patient's guideline for general Indian population.
\end{abstract}




\section{Introduction:-}

Ovarian cancer is one of the most common leading gynecological cancer in worldwide as well as India. (Age standardized incidence rate: 6.6/100000). Ovarian cancer has poor prognosis among all gynecological carcinoma [1]. The overall survival for five years is approximately $45 \%$ due to the advance stage at the time of diagnosis [2]. In Indian scenario ovarian cancer is third leading side of cancer among female next to cervical and breast cancer [1, 3]. Survival of ovarian cancer depends on various pathological and molecular factors [4, 5, 6, 7]. But nothing has been proved conclusive to be the best for overall survival of ovarian cancer. Prognosis of ovarian cancer can be depended on clinical factors, histopathological parameters and molecular based markers. Clinical factors include age, menopausal status and stage of the disease at diagnosis (FIGO). Histopathological parameters are type of carcinoma, tumor size, grade and lymph node metastasis. Several studies have reported that there are various prognostic markers in ovarian cancer [5,6,7]. The nuclear factor- $\kappa \mathrm{B}(\mathrm{NF}-\kappa \mathrm{B})$ family of genes are associated with cell proliferation, angiogenesis, metastasis, oncogenesis and survival of ovarian cancer [8, 9]. Some studies demonstrated that the association between NF- $\kappa \mathrm{B}$ and tumor progression commonly involved the p65 subunit [1113].NF- $\kappa B$ regulates over 500 genes involved in cellular transformation, survival, proliferation, invasion, angiogenesis, metastasis, and inflammation. The NF- $\kappa \mathrm{B}$ signaling pathway has become a potential therapeutic target [14].p53 expression is regulated by $\mathrm{NF}-\kappa \mathrm{B}$. Activation of $\mathrm{NF}-\kappa \mathrm{B}$ signaling pathway leads to the induction of target genes that can inhibit the apoptosis, interact with cell cycle regulation, cell invasion, contribute to tumourigenesis, inflammation and metastatic growth as well as chemo resistance and radio resistance in[15]. Activation of NF- $\kappa \mathrm{B}$ interacts with P53 mediated by up regulating anti-apoptotic genes and down regulating p53 levels with damaging survival cell. Recent studies repotted that p53 and NF- $\mathrm{B}$ are commonly mutated in variety of cancer [15]. The NF$\kappa \mathrm{B} / \mathrm{REL}$ family of transcription factors is included of a RELA/p65, c-REL, RELB, p105/NF- $\mathrm{B} 1$ and p100/NF- $\mathrm{BB} 2$ [10]. The members of this family are characterized by the presence of a REL homology domain (RHD) in the Nterminus, which is complex in sequence-specific DNA binding and translocation. The C-terminal regions of these proteins have domains responsible for either transcriptional activation (RELA, c-REL and RELB) or the inhibition of REL protein activity (p105 and p100). The p105 and p100 proteins can be processed by proteolytic cleavage into p50 and p52, respectively.NF- $\mathrm{B}$ interferes with the transcriptional movement of p53, an important determinant of stress- or DNA damage-induced apoptosis. Common transcriptional antagonism between p53 and NF- $\mathrm{B}$ includes competition for a regulating pool of their joint transcriptional coactivators, p300 and CREB-binding protein [23]. p53 also suppresses the expression of Bcl-3, a transcriptional coactivator of $\mathrm{p} 52 / \mathrm{NF}-\kappa \mathrm{B}$, so switching p52/Bcl-3 activator centers to p52/HDAC1 repressor complexes [24]. Such transcriptional interference has also been attributed to a direct interaction between p53 and RelA and NF-kB-mediated phosphorylation of p53 [25]. Finally, IKK2mediated activation of NF- $\kappa \mathrm{B}$ has been shown to protect cells from DNA damage-induced apoptosis by increasing Mdm2 levels and limiting the stabilization of p53 [26]. Irrespective of the specific mechanism(s) elaborated, the mutual antagonism between NF- $\kappa \mathrm{B}$ and p53 may regulate the balance between the expression of pro-apoptotic and survival genes. This study aims to validate the role of activation of $\mathrm{NF}-\kappa \mathrm{B} / \mathrm{p} 65$ as a prognostic marker for overall survival in patients with ovarian cancer in Indian subcontinent. The aim of our study was to usefulness of p53 activation as prognostic significance in ovarian cancer for overall-survival. This study aimed to find any association, if any, between the p53 and NF- $\mathrm{kB} / \mathrm{p} 65$ among the parameters such as age, menstrual status, stage of the disease, histopathology type, tumor size, grade and lymph node metastasis in ovarian cancer and was conducted for the first time with the ovarian cancer patients of Eastern India. The study was undertaken in the Institute of Post Graduate Medical Education \& Research (IPGME\&R) and Seth Sukhlal Karnani Memorial Hospital (SSKM), Kolkata, India.

\section{Materials and methods:- Patient selection:-}

The patients were divided into two groups, first group (Group-A) comprised of 106 female patients with ovarian carcinoma previous untreated by chemotherapy, radiotherapy, hormone therapy or a combination of any of the modalities who presented at outpatient door in our institute, Kolkata, West Bengal, India between 2009 and 2011 were included in this research work and was followed up for 5 years. 32 female patients who were histological and clinically benign ovarian disease treated as control group (Group-B). One part of the tissue ovarian carcinoma tumors were fixed in $10 \%$ neutral-buffered formalin for $24 \mathrm{~h}$, measured the tumor size, nodal status, grade and embedded in paraffin and sectioned. All patients were followed up for a period of five years. Information of these patients was maintained in the department of $\mathrm{G} \& \mathrm{O}$ in this institute. All patients were treated with standard therapeutic protocol like surgery followed by chemotherapy /radiotherapy as appropriate. Patients were followed up monthly for the first three months and then once in four months for the rest of the period. Survival period was calculated from the date of surgery to the date of last contact of the patients. 


\section{Tissue Processing:-}

Another part of the ovarian cancer tissue, the specimens were washed with phosphate buffered saline (PBS), cut into small pieces and immersed in collagenase at $37^{\circ} \mathrm{C}$ for $4-6 \mathrm{hrs}$. Collagenase incubated tissue was minced and treated with $0.125 \%$ trypsin-EDTA for $10 \mathrm{~min}$. Total protein was extracted by homogenizing cells in ripa : lysis buffer mixture (1:3) at $4^{\circ} \mathrm{C}$ and measured spectrophotometrically by Lowry's method.

\section{Western Blot analysis:-}

For whole cell lysates, cells were suspended and homogenized in buffer $(100 \mathrm{mM}$ Tris- $\mathrm{Cl}, \mathrm{pH} 7.4,300 \mathrm{mM} \mathrm{NaCl}, 1 \%$ NP-40, and $0.25 \%$ sodium-deoxycholate). All the buffers were supplemented with protease and phosphatase inhibitor mixtures. For direct Western blot analysis, the cell lysates or the particular fractions were separated by SDS-PAGE, transferred to nitrocellulose membrane (AmershamHybond-P, GE Healthcare) and probed with specific antibodies, e.g., anti $-\mathrm{p} 65(\mathrm{NF}-\mathrm{kB})$ and anti $-\mathrm{p} 53$ produced from Santa Cruz thereafter the immunoblots were visualized by chemiluminescence or alkaline phosphatase method. Equal protein loading was confirmed with $\alpha$-actin antibody (Santa Cruz).

\section{Statistical Analysis:-}

For statistical analysis data were entered into a Microsoft excel spreadsheet and then analyzed by SPSS 20.0 .1 and GraphPad Prism version 5. Without other qualification, 'chi-squared test' often was used as short for Pearson's chisquared test. Unpaired proportions were compared by Chi-square test or Fischer's exact test, as appropriate. The Kaplan-Meier estimator (Kaplan-Meier survival analysis) was a non-parametric statistic used to estimate the survival function from time data. $\mathrm{p}$-value $\leq 0.05$ was considered for statistically significant.

\section{Results:-}

In present study, NF- $\mathrm{kB}$ was overexpressed with 66(66.2\%) patients and p53 was activated with $69(65.21 \%)$ patients in ovarian carcinoma but both NF- $\mathrm{KB}$ and p53 was not activated in benign ovarian tumor. It was found that $73(68.9 \%)$ patients were in age group $>40$ years whereas $33(31.1 \%)$ patients were in age group $\leq 40$ years. 69 (65.1\%) patients were in premenopausal women but 37(34.9\%) patients were in postmenopausal women. In present study, it was showed that 11(10.4\%) patients had in stage -I, 17(16.0\%) patients had in stage-II, 61(57.5\%) patients had in stage-III and $17(16.0 \%)$ patients had in stage-IV.

As per table-1, 20(60.6\%) NF- $\mathrm{KB}$ positive patients were in $\leq 40$ years age group and $46(63.0 \%) \mathrm{NF}-\mathrm{\kappa B}$ positive patients were in $>40$ years age group but this was not statistically significant $(\mathrm{p}=0.8128)$. It was showed that $44(66.7 \%)$ premenopausal patients and 20(54.1\%) postmenopausal patients were in NF- $\mathrm{\kappa B}$ positive tumor but this was not statistically significant ( $\mathrm{p}=0.2016$ ). According to clinical staging, NF- $\kappa B$ positive tumors were found in 2 (18.2\%) tumors with stage I, 3(17.6\%) tumors with stage II, 46(75.4\%) tumors with stage III and $15(88.2 \%)$ tumors with stage IV. This association was statistically significant $(\mathrm{p}<0.0001)$.

According to histopathological grading, 2(18.2\%) in grade-I, 9(34.6\%) in grade-II and 55(79.7\%) in grade-III

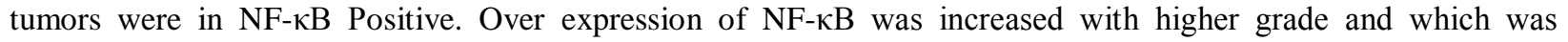
statistically significant $(\mathrm{p}<0.0001)$.NF- $\mathrm{\kappa B}$ was activated 10(90.9\%) tumor with Clear Cell Carcinoma, 14(53.8\%) tumor with Mucinous Carcinoma and 42(71.2\%) tumor with Serous Carcinoma. This association was statistically significant $(\mathrm{p}<0.0001) .2(50.0 \%)$ patients with T1 tumors, 30(52.6\%) patients with T2 tumors and 34(75.6\%) with T3 tumors were NF- $\mathrm{KB}$ positive but this was not statistically significant $(\mathrm{p}=0.0526)$. Patients with lymph node negative tumors $5(19.2 \%)$ and lymph node positive tumors $61(76.3 \%)$ were found with NF- $\mathrm{KB}$ positive tumors and this association was statistically significant $(\mathrm{p}<0.001)$.

As per table-2, 22(66.7\%) p53 positive patients had in age group $\leq 40$ years and $47(64.4 \%)$ p53 positive patients had in age group $>40$ years but this was not statistically significant $(\mathrm{p}=0.8193) .47(68.1 \%)$ premenopausal patients and 22(59.5\%) postmenopausal patients were in p53 positive tumors but this was not statistically significant $(\mathrm{p}=0.3728)$.In the $\mathrm{p} 53$ positive tumors, $3(27.3 \%)$ had stage I, $5(29.4 \%)$ had stage II, $47(77.0 \%)$ had stage III and $14(82.4 \%)$ had stage IV disease. This association was statistically significant $(\mathrm{p}<0.0001)$.

In grade I, 3(27.3\%) out of 11 patients, in grade II 11 (42.3\%) out of 26 patients, in grade III 55(79.7\%) out of 69 patients were p53 positive which was statistically significant $(\mathrm{p}=0.0001)$. According to histopathology type of ovarian carcinoma, 1(9.1\%) patient was Clear Cell Carcinoma, 1(10.0\%) patient was Endometrioid Carcinoma, 16(61.5\%) patients were Mucinous Carcinoma and 51(86.4\%) were Serous Carcinoma with p53 positive and this 
association was statistically significant ( $\mathrm{p}<0.0001) . \mathrm{p} 53$ was activated in 3(75.0\%), 34(59.6\%) and 32(71.1\%) patients with $\mathrm{T} 1, \mathrm{~T} 2$ and $\mathrm{T} 3$ tumor size respectively but this was not statistically significant $(\mathrm{p}=0.4419)$. Patients with lymph node negative tumors $9(34.6 \%)$ and lymph node positive tumors $60(75.0 \%)$ were found with p53 positive tumors and this association was statistically significant $(\mathrm{p}<0.0001)$.

As per table-3, 4(10.0\%) patients died with NF- $\kappa \mathrm{B}$ negative tumors for five years overall survival periods whereas $50(75.8 \%)$ patients died with NF- $\kappa \mathrm{B}$ positive tumors for five years overall survival periods. This difference was statistically significant $(\mathrm{p}<0.0001) .5(13.5 \%)$ patients died with $\mathrm{p} 53$ negative tumors for five years overall survival periods whereas $49(71.0 \%$ ) patients died with p53 positive tumors for five years overall survival periods.

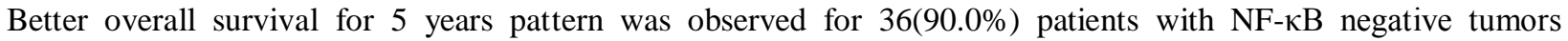
compared to $16(24.2 \%)$ patients with NF-kB positive tumors which was statistically significant (Log-rank Statistic 40.35; $\mathrm{p}<0.0001)$, (Table-5; Figure 1).

The overall survival for 32(86.5\%) patients with p53 negative tumors was better than 20(29.0\%) with p53 positive tumors which was statistically significant (Log-rank Statistic - 26.66; p<0.0001); (Table-5; Figure 2).

Table-1:- Clinical and Pathological details according to NF- $\mathrm{kB}$ status

\begin{tabular}{|c|c|c|c|c|c|c|}
\hline \multirow[t]{2}{*}{ Table:1 } & \multirow[t]{2}{*}{$x^{2}+x^{2}$} & \multicolumn{2}{|c|}{ NF-кB Negative } & \multicolumn{2}{|c|}{ NF-кB Positive } & \multirow{2}{*}{ p-Value } \\
\hline & & Number & Percentage & Number & Percentage & \\
\hline \multirow[t]{2}{*}{ Age (Years) } & $\leq 40$ & 13 & 39.4 & 20 & 60.6 & \multirow[t]{2}{*}{0.8128} \\
\hline & $>40$ & 27 & 37.0 & 46 & 63.0 & \\
\hline \multirow{2}{*}{$\begin{array}{l}\text { Menopausal } \\
\text { Status }\end{array}$} & Pre & 23 & 33.3 & 46 & 66.7 & \multirow[t]{2}{*}{0.2016} \\
\hline & Post & 17 & 45.9 & 20 & 54.1 & \\
\hline \multirow[t]{4}{*}{ Stage } & I & 9 & 81.8 & 2 & 18.2 & \multirow[t]{4}{*}{$<0.0001$} \\
\hline & II & 14 & 82.4 & 3 & 17.6 & \\
\hline & III & 15 & 24.6 & 46 & 75.4 & \\
\hline & IV & 2 & 11.8 & 15 & 88.2 & \\
\hline \multirow[t]{3}{*}{ Grade } & I & 9 & 81.8 & 2 & 18.2 & \multirow[t]{3}{*}{$<0.0001$} \\
\hline & II & 17 & 65.4 & 9 & 34.6 & \\
\hline & III & 14 & 20.3 & 55 & 79.7 & \\
\hline \multirow[t]{4}{*}{$\begin{array}{l}\text { Histopathology } \\
\text { Type }\end{array}$} & $\begin{array}{l}\text { Clear Cell } \\
\text { Carcinoma }\end{array}$ & 1 & 9.1 & 10 & 90.9 & \multirow[t]{4}{*}{$<0.0001$} \\
\hline & $\begin{array}{l}\text { Endometrioid } \\
\text { Carcinoma }\end{array}$ & 10 & 100.0 & 0 & 0.0 & \\
\hline & $\begin{array}{l}\text { Mucinous } \\
\text { Carcinoma }\end{array}$ & 12 & 46.2 & 14 & 53.8 & \\
\hline & $\begin{array}{l}\text { Serous } \\
\text { Carcinoma }\end{array}$ & 17 & 28.8 & 42 & 71.2 & \\
\hline \multirow[t]{3}{*}{ Tumor Size } & T1 & 2 & 50.0 & 2 & 50.0 & \multirow[t]{3}{*}{0.0526} \\
\hline & T2 & 27 & 47.4 & 30 & 52.6 & \\
\hline & T3 & 11 & 24.4 & 34 & 75.6 & \\
\hline \multirow[t]{2}{*}{ Nodal Status } & Negative & 21 & 80.8 & 5 & 19.2 & \multirow[t]{2}{*}{$<0.0001$} \\
\hline & Positive & 19 & 23.8 & 61 & 76.3 & \\
\hline
\end{tabular}

Table-2:- Relationship between pathological details and p53 status

\begin{tabular}{|c|c|c|c|c|c|c|}
\hline \multirow[t]{2}{*}{ Table:2 } & & \multicolumn{2}{|c|}{ p53 Negative } & \multicolumn{2}{|c|}{ p53 Positive } & \multirow[t]{2}{*}{ p-Value } \\
\hline & & Number & Percentage & Number & Percentage & \\
\hline \multirow{2}{*}{ Age (Years) } & $\leq 40$ & 11 & 33.3 & 22 & 66.7 & \multirow[t]{2}{*}{0.8193} \\
\hline & $>40$ & 26 & 35.6 & 47 & 64.4 & \\
\hline \multirow{2}{*}{$\begin{array}{l}\text { Menopausal } \\
\text { Status }\end{array}$} & Pre & 22 & 31.9 & 47 & 68.1 & \multirow[t]{2}{*}{0.3728} \\
\hline & Post & 15 & 40.5 & 22 & 59.5 & \\
\hline \multirow[t]{2}{*}{ Stage } & I & 8 & 72.7 & 3 & 27.3 & \multirow[t]{2}{*}{0.0001} \\
\hline & II & 12 & 70.6 & 5 & 29.4 & \\
\hline
\end{tabular}




\begin{tabular}{|c|c|c|c|c|c|c|}
\hline & III & 14 & 23.0 & 47 & 77.0 & \\
\hline & IV & 3 & 17.6 & 14 & 82.4 & \\
\hline \multirow[t]{3}{*}{ Grade } & I & 8 & 72.7 & 3 & 27.3 & \multirow[t]{3}{*}{0.0001} \\
\hline & II & 15 & 57.7 & 11 & 42.3 & \\
\hline & III & 14 & 20.3 & 55 & 79.7 & \\
\hline \multirow[t]{4}{*}{$\begin{array}{l}\text { Histopathology } \\
\text { Type }\end{array}$} & $\begin{array}{l}\text { Clear Cell } \\
\text { Carcinoma }\end{array}$ & 10 & 90.9 & 1 & 9.1 & \multirow[t]{4}{*}{$<0.0001$} \\
\hline & $\begin{array}{l}\text { Endometrioid } \\
\text { Carcinoma }\end{array}$ & 9 & 90.0 & 1 & 10.0 & \\
\hline & $\begin{array}{l}\text { Mucinous } \\
\text { Carcinoma }\end{array}$ & 10 & 38.5 & 16 & 61.5 & \\
\hline & $\begin{array}{l}\text { Serous } \\
\text { Carcinoma }\end{array}$ & 8 & 13.6 & 51 & 86.4 & \\
\hline \multirow[t]{3}{*}{ Tumor Size } & T1 & 1 & 25.0 & 3 & 75.0 & \multirow[t]{3}{*}{0.4419} \\
\hline & T2 & 23 & 40.4 & 34 & 59.6 & \\
\hline & T3 & 13 & 28.9 & 32 & 71.1 & \\
\hline \multirow[t]{2}{*}{ Nodal Status } & Negative & 17 & 65.4 & 9 & 34.6 & \multirow[t]{2}{*}{$<0.0001$} \\
\hline & Positive & 20 & 25.0 & 60 & 75.0 & \\
\hline
\end{tabular}

Table-3:- Association of overall survival according toNF-кB and $\mathrm{p} 53$ status

\begin{tabular}{|l|l|l|l|l|l|l|}
\hline \multirow{2}{*}{ Table:3 } & Status & Death & Alive & \multirow{2}{*}{ p-Value } \\
\cline { 3 - 7 } & & Number & Percentage & Number & Percentage & \\
\hline \multirow{2}{*}{ NF-אB } & Negative & 4 & 10.0 & 36 & 90.0 & $<0.0001$ \\
\cline { 2 - 7 } & Positive & 50 & 75.8 & 16 & 24.2 & \\
\hline \multirow{2}{*}{ p53 } & Negative & 5 & 13.5 & 32 & 86.5 & $<0.0001$ \\
\cline { 2 - 6 } & Positive & 49 & 71.0 & 20 & 29.0 & \\
\hline
\end{tabular}

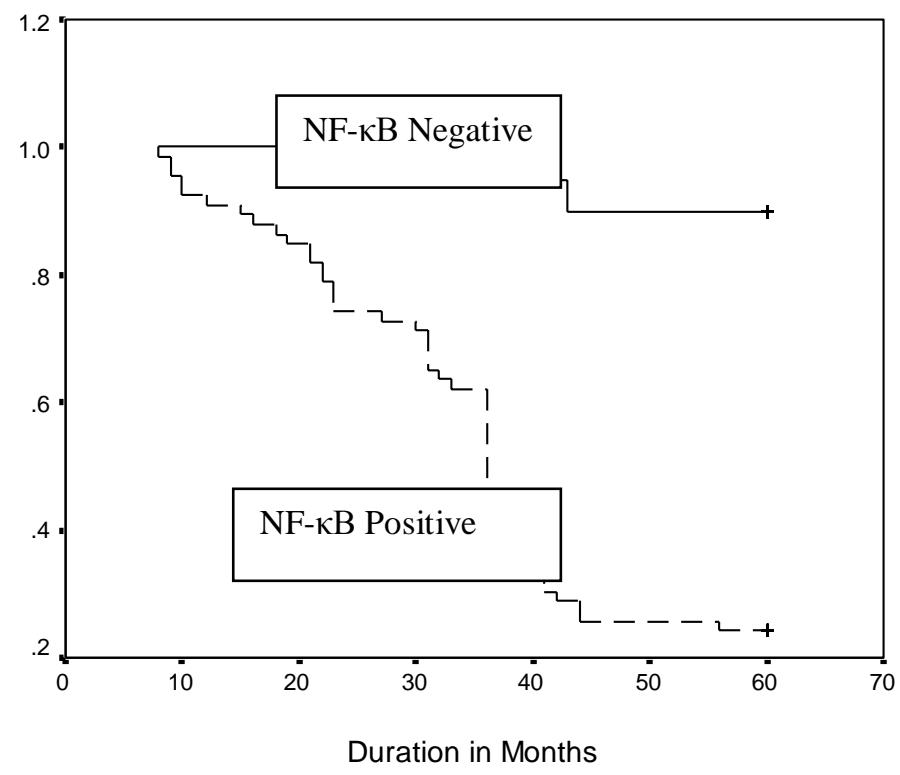

Figure-1:- Kaplan-Meier survival curve showing five years overall survival for patients with NF- $\kappa B$ positive and NF- $\kappa B$ negative tumors (Log-rank Statistic: 40.35; $\mathrm{p}<0.0001$ ). 


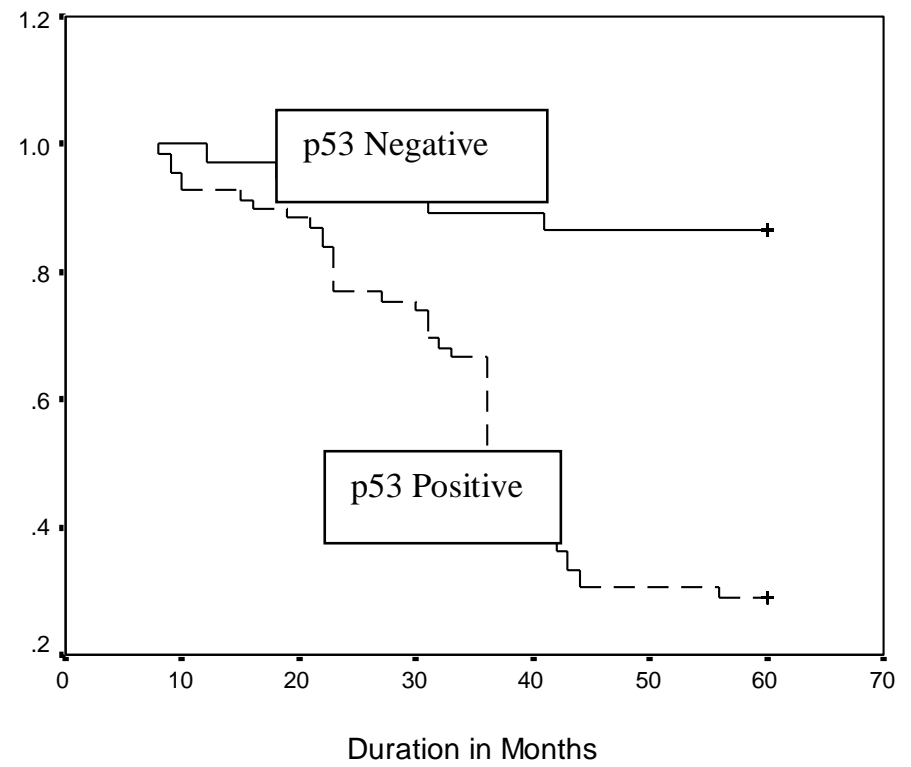

Figure-4:- Kaplan-Meier survival curve showing five years overall survival for patients with p53 positive and p53 negative tumors (Log-rank Statistic: 26.66; p<0.0001).

\section{Discussion:-}

In this study, activation of NF- $\kappa \mathrm{B}$ and p53 was higher proportion (66.2\% and $65.21 \%)$ in ovarian carcinoma but both $\mathrm{NF}-\kappa \mathrm{B}$ and $\mathrm{p} 53$ was not activated in benign ovarian tumor. Various study reported that there are various prognostic factors in survival for ovarian cancer [4, 5, 6, and 7]. In present study, high grade tumor was associated with poor prognosis and a large proportion of these tumors were observed to be NF- $\kappa$ B positive. There was strong association between lymph node metastasis among p53 positive tumors and NF- $\kappa \mathrm{B}$ activation. NF- $\kappa \mathrm{B}$ positive tumors showed higher number in T3 tumor. NF- $\kappa \mathrm{B}$ positivity was observed in advanced stage of disease like stage-III and stage-IV. Activation of p53 was directly related with NF- $\kappa \mathrm{B}$ positive tumors. This implies that NF- $\kappa \mathrm{B}$ is associated with aggressive tumor biology such as large T-Size, high grade and poor differentiation. D. Jana et al suggested that overexpression $\mathrm{NF}-\kappa \mathrm{B}$ was poor prognostic marker and also associated with higher grade, advance stage, large tumor size and more lymph node metastasis in breast cancer [16]. It was found that activation of NF- $\kappa \mathrm{B}$ was significantly associated with advanced stage, (stage-III and stage-IV) in ovarian cancer. Christina $\mathrm{M}$ at al demonstrates that role of NF- $\kappa \mathrm{B}$ progression was correlated with advanced ovarian cancer [17]. Various study reported that $\mathrm{NF}-\kappa \mathrm{B}$ was a poor prognostic marker in ovarian cancer $[18,19,20]$. No correlation was found between $\mathrm{NF}-\kappa \mathrm{B}$ expression vs age at diagnosis. Use of several compounds for inhibition of NF- $\kappa \mathrm{B}$ activity was an important role in treatment and prevention of various cancers [21]. Activation of p53 was associated with high grade and advance stage in epithelial ovarian carcinoma. Lynn $\mathrm{C}$ at al found that p53 expression was significantly correlated with decrease overall survival by using univarate analysis [22]. So abnormality of p53 was found commonly in patients with ovarian carcinoma in our scenario. NF- $\mathrm{B}$ promotes tumor genesis, cell cycle progression, angiogenesis, proliferation and survival of ovarian cancer[16].NF- $\kappa \mathrm{B}$ expression was directly correlated with advance stage, higher grade, large tumor size, and more limb node metastasis, which implies a poor prognosis. High level of p53 and NF- $\mathrm{B}$ B were associated with poor overall survival in ovarian cancer patients. The key role of NF$\kappa \mathrm{B}$ signaling is regulating the differentiation of the ovarian cancer cell: coupled with the fact that dysregulation of this pathway is associated with adverse clinico pathological parameters, making it a potential target for anti-cancer therapeutic application.

\section{Conclusion:-}

Being one of the pioneer studies on ovarian cancer overall survival of eastern India this study provided some knowledge of pattern of survival of ovarian cancer. NF- $\kappa \mathrm{B}$ and p53 overexpression was associated with large tumor size, high grade, positive lymph node metastasis and Serous Carcinoma which is poor prognostic outcome of the disease. We concluded that NF- $\mathrm{BB}$ and $\mathrm{p} 53$ expression was significantly correlated with advance stage and poor overall survival. Inhibition $\mathrm{NF}-\kappa \mathrm{B}$ overexpression may reduction tumor advancement in patients and may block 
carcinogenesis, reducing the incidence of ovarian carcinoma in patients at high risk. In conclusion, Activation of NF- $\mathrm{kB}$ implies aggressive tumor biology with p53 mediated in ovarian carcinoma $\&$ it can predict tumors likely to have poor prognosis. Patients with NF- $\mathrm{KB}$ and $\mathrm{p} 53$ positive tumors need to be treated aggressively in clinical practice.

\section{Acknowledgment:-}

It is our unlimited pleasure to the Department of Science \& Technology, New Delhi, India for funding the research work. It is our great pleasure \& proud privilege to express our gratitude to the Director and the Head of the Department of Gynecology \& Obstetrics of I P G M E \& R, Kolkata. They constantly helped us in completing this work. We must express our deep sense of obligation and gratitude to the Ethical Committee of IPGME \& R, Kolkata, for their kind permission to carry out this study in this Institution. We also remember the help that we received from The Head of the Department of Pathology, IPGME\&R, and Kolkata. Special thanks to our patients for their continuing co-operation.

\section{References:-}

1. Basu P., De P., Mandal S., Ray K., Biswas J.,"Study of 'patterns of care' of ovarian cancer patients in a specialized cancer institute in Kolkata, eastern India,"Indian Journal of Cancer, vol. 46, no. 1, pp. 28-33, 2009.

2. Jemal A., Siegel R., Ward E., Murray T., Xu J., Smigal C., et al,"Cancer statistics, 2006,"CA Cancer J Clin, vol. 56, no. 2, pp. 106-130, 2006.

3. D. Jana, S. Mandal, M. Mukhopadhyay, D. Mitra, S. K Mukhopadhyay, D. K. Sarkar,"Prognostic Significance of HER-2/neu and Survival of Breast Cancer Patients Attending a Specialized Breast Clinic in Kolkata, Eastern India," Asian Pacifc J Cancer Prev, vol. 13, no. 8, pp. 3851-3855, 2012.

4. F. Legge, G. Ferrandina, V. Salutari\& G. Scambia,"Biological characterization of ovarian cancer: prognostic and therapeutic implications," Annals of Oncology, vol. 16 no. 4, pp. iv95-iv101, 2005.

5. G. Yang, X. Xiao, D. G. Rosen, X. Cheng, X. Wu, B. Chang, et al,“ The Biphasic Role of NF-kB in Progression and Chemoresistance of Ovarian Cancer," Clin Cancer Res, vol. 17, no. 8, pp. 2181-2194, 2011.

6. Vollan H.K., Rueda O.M., Chin S.F., Curtis C., Turashvili G., Shah .S, et al, "A tumor DNA complex aberration index is an independent predictor of survival in breast and ovarian cancer," MolOncol, vol. 9, no. 1, pp. 115-27, 2015.

7. M. Chen, Y. Jin, Y. Bi, Y. Li, Y. Shan, L. Pan,"Prognostic Significance of Lymphovascular Space Invasion in Epithelial Ovarian Cancer,"Journal of Cancer, vol. 6, no. 5,pp. 412-419, 2015.

8. G. Sethi and V. Tergaonkar,"Potential pharmacological control of the NF-kB pathway," Cell, vol. 30, no. 6,pp. 313-321, 2009.

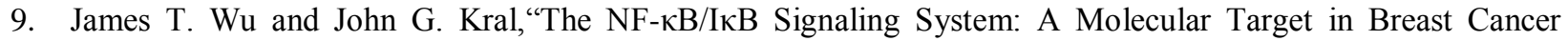
Therapy," Journal of Surgical Research, vol. 123, no 1, pp. 158-169, 2005.

10. L.F. Chen and W.C. Greene, "Shaping the nuclear action of NF-kappaB,"Nature Rev, vol. 5, no. 5, pp. 392-401, 2004.

11. Fradet V, Lessard L, Bégin LR, Karakiewicz P, Masson AM and Saad F,"Nuclear factor-kappaB nuclear localization is predictive of biochemical recurrence in patients with positive margin prostate cancer," Clin Cancer Res, vol. 10, no. 24, pp. 8460-8464, 2004.

12. Ross JS, Kallakury BV, Sheehan CE, Fisher HA, Kaufman RP Jr, Kaur P, et al, "Expression of nuclear factorkappa B and I kappa B alpha proteins in prostatic adenocarcinomas: correlation of nuclear factor-kappa B immunoreactivity with disease recurrence,"Clin Cancer Res, vol. 10, no. 7, pp. 2466-2472, 2004.

13. Kleinberg L, Dong HP, Holth A, RisbergB, Trope' CG, Nesland JM, et al,"Cleaved caspase-3 and nuclear factor-kappaB p65 are prognostic factors in meta-static serous ovarian carcinoma,"Hum Pathol, vol. 40, no. 6, pp. 795-806, 2009.

14. S. C. Gupta, C. Undaram, S. Reuter, B. B Aggarwal,"Inhibiting NF- $\kappa$ B activation by small molecules as a therapeutic strategy," BiochimicaBiophysicaActa, vol. 1799, no. 10-12,pp. 775-787, 2010.

15. F. R. Greten and M. Karin,"The IKK/NF-кB activation pathway-a target for prevention,"Cancer Letters, vol. 206, no. 2, pp. 193-199, 2004.

16. D. Jana, S. Das, D. K. Sarkar, S. Mandal, A. Maji, M. Mukhopadhyay,"Role of Nuclear Factor-kB in female Breast Cancer: A Study in Indian Patients"Asian Pacifc J Cancer Prev,vol. 13, no. 11, pp. 5511-5515, 2012.

17. Annunziata CM, Stavnes HT, Kleinberg L, Berner A, Hernandez LF, Birrer MJ, et al, "NF- $\mathrm{KB}$ transcription factors are co-expressed and convey poor outcome in ovarian cancer," Cancer, vol. 116, no. 13, pp, 3276-3284, 2010. 
18. Yang G, Xiao X, Rosen DG, Cheng X, Wu X, Chang B, et al,"The Biphasic Role of NF- $\kappa$ B in Progression and Chemoresistance of Ovarian Cancer," Clin Cancer Res,vol. 17, no. 8, pp. 2181-2194, 2011.

19. Kleinberg L, Dong HP, Holth A, RisbergB, Trope' CG, Nesland JM, et al,"Cleaved caspase-3 and nuclear factor-kappaB p65 are prognostic factors in metastatic serous ovarian carcinoma," Hum Pathol, vol. 40, no. 6, pp. 795-806, 2009.

20. Annunziata CM, Stavnes HT, Kleinberg L, Berner A, Hernandez LF, Birrer MJ, et al,"Nuclear factor kappaB transcription factors are coexpressed and convey a poor outcome in ovarian cancer," Cancer, Vol.116, no. 13, pp. 3276-3284, 2010.

21. Sarkar DK, Jana D, Patil PS, Chaudhari KS, Chattopadhyay BK, Chikkala BR, "Role of NF-kB as a Prognostic Marker in Breast Cancer: A Pilot Study in Indian Patients,"Indian J SurgOncol, vol. 13, no. 3, pp. 0234-0238, 2013.

22. L C Hartmann, K C Podratz, G L Keeney, N A Kamel, J H Edmonson, J P Grill, et al, "Prognostic significance of p53 immunostaining in epithelial ovarian cancer,"Journal of Clinical Oncology, vol. 12, no. 1,pp.64-69, 1994

23. R. Ravi, A. Bedi,"NF-кB in cancer-a friend turned foe,"Drug Resistance Updates, vol. 7, no. 1,pp. 53-67, 2004.

24. Rocha, S., Martin, A.M., Meek, D.W., Perkins, N.D., "p53 represses cyclin D1 transcription through down regulation of Bcl-3 and inducing increased association of the p52 NF-kappaB subunit with histone deacetylase," Mol. Cell Biol, vol. 23, no. 13, pp. 4713-4727, 2003.

25. 25.Ikeda A, Sun X, Li Y, Zhang Y, Eckner R, Doi TS, et al., "p300/CBP-dependent and independent transcriptional interference between NF-kappaBRelA and p53," Biochem. Biophys. Res. Commun, vol. 272, no. 2, pp. 375-379, 2000.

26. Tergaonkar, V., Pando, M., Vafa, O., Wahl, G., Verma, I.,"p53 stabilization is decreased upon NFkappaB activation: a role for NFkappaB in acquisition of resistance to chemotherapy," Cancer Cell, vol. 1, no. 5, pp. 493-503, 2002. 